\title{
Cultural Awareness among First-Year Undergraduate Students of English and Translation
}

\begin{abstract}
The article presents the results of a culture quiz that was administered among undergraduate students of English and Translation at the University of Maribor in 2019. Comprising twenty items from five domains of culture that the respondents had to identify, the results of the quiz showed that that the students were most familiar with items from the domains of technology and its closely related vocabulary, followed by sports, politics and high culture (drama, literature, ballet). The study also suggested some differences based on respondents' gender and their high school grade performance in English. The results partly overlap with the results of a similar study from 2007, corroborating that popular culture remains the most recognizable cultural domain among the surveyed students.
\end{abstract}

Keywords: quiz, cultural awareness, survey, students, English and Translation Studies

\section{Kulturna ozaveščenost dodiplomskih študentov prvega letnika anglistike in prevajalstva}

POVZETEK

V prispevku so predstavljeni rezultati kulturološkega kviza, v katerem so v letu 2019 sodelovali dodiplomski študenti anglistike ter prevajalstva na Univerzi v Mariboru. Kviz je sestavljalo dvajset pojmov s petih tematskih področij, ki so jih morali sodelujoči na kratko pojasniti. Rezultati so pokazali, da študenti najbolje poznajo področje tehnologije in izrazje, povezano s tehnologijo, čemur so sledili pojmi s področja športa, politike in visoke kulture. Ugotovljeni sta bili povezavi s spolom sodelujočih in z njihovo oceno iz angleščine pri maturi. Rezultati raziskave delno sovpadajo z rezultati podobne raziskave leta 2007 in potrjujejo, da popkultura na širšem polju kulture ostaja njen najbolj prepoznaven del.

Ključne besede: kviz, kulturna ozaveščenost, raziskava, študenti, anglistika in prevajalstvo 


\section{Introduction}

Current generations of Slovenian university students have been growing up in a world different to that of the generations before them. A few decades ago, for example, the only source of daily news for the citizens of the then Yugoslavia were the state-controlled media. In addition, travel was restricted, further limiting knowledge about the world beyond the Yugoslav borders. Today's students, on the other hand, live a different life. Not only has modern technology made it possible for them to follow events from virtually every corner of the world as they unfold; but globalization has also provided the young with practically unlimited travel opportunities. The changed situation raises many questions: How aware are students of the culture surrounding them? How closely do they follow the latest developments? How sensitive are they to the events in their own culture and in other cultures? What are their main fields of interest? Do they mostly follow "low" or "high" culture? Does access to large amounts of information have an impact on their cultural awareness? Given that "the lives and experiences of youth growing up today will be linked to economic realities, social processes, technological and media innovations, and cultural flows that traverse national boundaries with ever greater momentum" (Suárez-Orozco and Baolian Qin-Hilliard 2004, 2), the authors of this paper decided to test the cultural awareness of first-year undergraduate students of the English Language and Literature program and of the Translation Studies program (English variant) at the University of Maribor. The study was carried out with a culture quiz designed by the authors. The article has three parts: the first presents the concept of cultural awareness, the second the quiz design and methodology and the third the results of the quiz, followed by a discussion of results and the concluding remarks.

\section{Cultural Awareness}

The Collins COBUILD Advanced English Dictionary defines someone's cultural awareness as "their understanding of the differences between themselves and people from other countries or other backgrounds, especially differences in attitudes and values" (2020). From the point of view of the present study, the definition has three important implications. First, its inclusion in a comprehensive dictionary suggests that "cultural awareness" represents an established concept in Modern English. Second, the definition indicates the existence of the two types of cultural awareness: the intracultural and intercultural. The intracultural concerns the understanding of the differences in one's own culture, while the intercultural concerns the understanding of the differences between one's own and other cultures. Third, the ability to distinguish between different types of cultural awareness represents an important dimension of language teaching. English, for example, is typically associated with a specific culture or nation such as the United Kingdom, Australia or the United States. However, given that English is a global lingua franca, it is also necessary to keep in mind that "an awareness of the dynamic relationship between English and its diverse multicultural settings of English use, therefore, should be a key element of any attempt to teach communication" (Baker 2012, 69). In other words, familiarization with the various aspects of culture alone does not suffice; instead, future teachers (and translators) must also know how to connect that knowledge with language use in a variety of contexts. This, at the same time, is the main argument for an integrated approach to language and culture pedagogy (Shaules 2019). 
As is known from the sociology of knowledge, understanding one's own and other cultures is determined by the individual's socialization process. In their influential monograph The Social Construction of Reality, Berger and Luckmann ([1966] 1991) highlight the two main stages of this process: primary and secondary socialization. Primary socialization takes place at a young age and refers to the ways in which the "significant others", in most cases close family members, mediate the world for their dependents, modifying it in line with their own place in the social structure (Berger and Luckmann [1966] 1991, 150-51). Secondary socialization, on the other hand, includes the internalization of institution-based knowledge that individuals encounter in the course of their formal schooling and training (Berger and Luckmann [1966] 1991, 158). Both help individuals become members of society and grow into their respective cultures.

In addition to social contact, cultural knowledge is acquired through exposure to literature, music, film, radio, television, museums, galleries and other facets of a given culture. As a result, the means and processes of socialization and acculturation change over time. In the 1950s, for example, the grandparents of most of today's students grew up in Yugoslavia, a Socialist Eastern Bloc country still recovering from war, where the main (and often only) sources of news were the state-controlled radio and newspapers. Cultural institutions were also in one way or another under the influence of the political system and the dominant ideology. In addition, mobility was limited and travel to the West "was typically only the privilege of diplomats and those who traveled for business" (Turudić 2008). Hence, most people had a limited view of their own and particularly other cultures. University students of our time are different. Generation Z, which includes those born between the mid-1990s and the early noughties, has not only enjoyed a higher standard of living and cheaper and more accessible long-distance travel (Castles 2009, 2050), but is also the first that has "never known a world without the Internet" (Corey and Grace 2019, 40). In addition, mobile phones' primary function of providing voice communication with smartphones is being increasingly complemented by the secondary functionality, accessing information online (Bratina 2019). This, among other things, has made it possible to follow the news about the developments at home and abroad at any given moment. The question remains, however, how access to large amounts of information affects the cultural awareness of young people.

Cultural awareness has been the subject of scholarly interest for a long time. Studies have been particularly common in the fields directly involving two or more cultures, such as translation, healthcare or teaching. Depending on the field, the foci differ. In translation and conference interpreting, cultural awareness and its related terms such as (cross-)cultural competence or cultural sensitivity emphasize the translators' and interpreters' awareness of the multiple facets of various cultures associated with the source and target languages (e.g. González Davies and Scott-Tennent 2005; Hale 2013; Tellinger 2016; Eyckmans 2017). Such an understanding of cultural awareness is also reflected in the framework documents. ISO $(2015,11)$ standards for translators, for example, define cultural competence of translators as "the ability to make use of information about the locale, behavioural standards, and value systems that characterize the source and target cultures". Similarly, the guiding principles for translator training programs in Europe (EMT Expert Group 2009) see intercultural competence as one of the six interdependent sub-competences of translation competence, comprising sociolinguistic and 
textual dimensions. The former refers to the ability to recognize various social, geographical, historical and stylistic varieties and registers of language; and the latter the ability to "grasp presuppositions, implicit allusions and stereotypes and to identify culture-bound values and references, and also the ability to compare cultural elements and methods of composition" (Eyckmans 2017, n.p.). As the definitions show, emphasis falls on the linguistic facets of the contact between two or more cultures. In healthcare settings, on the other hand, cultural competence goes beyond just improving communication from a linguistic standpoint, aspiring to "enhance responsiveness to the healthcare needs of diverse patients; reduce healthcare provider discrimination; and reduce healthcare disparities" (Shepherd et al. 2019, 2). In North America, cultural competence gained in importance ${ }^{1}$ after research and reports showed that "particular cultural groups are more likely to be underserved, perceive negative treatment, and receive differential treatment outcomes" (Shepherd et al. 2019, 2). Typically, the main target groups included immigrant populations with limited knowledge of English and limited exposure to Western cultural norms (Saha, Beach and Cooper 2008, 1278). As a result, cross-cultural training for healthcare professionals has become commonplace and even mandatory (Shepherd et al. 2019,2) and has led to specialized publications addressing various target groups (e.g. Paez et al. 2009; Collette et al. 2013; Holland 2018; Kerber et al. 2019) or fields of medicine (e.g., Parekh 2014; Daugherty and Kearney 2017). One of the central objectives of cross-cultural healthcare is:

the importance of recognizing that both patients and providers brought cultural perspectives to the encounter. As such, healthcare providers were encouraged to acknowledge and explore their own cultural influences, including those acquired through their training in western biomedicine and entry into the health professions. (Saha, Beach, and Cooper 2008, 1278)

An overview of the literature has shown the importance of both external measurement of and self-reflection on degrees of cultural awareness.

Participants in this study, though not in healthcare professions, are all embarked on language study that could lead to equally culturally interactive professions, such as teaching, translation and interpreting. With globalization, migration and increased mobility of students, cultural awareness has also gained in prominence in education. For educators in many parts of the Western world, one major challenge today is how to teach in a multicultural classroom. In the past, the populations of most Western nations were relatively homogenous; for quite some time, however, their ethnic, racial, linguistic and religious minorities have been increasing much faster than their mainstream groups (see McAllister and Jordan Irvine 2000; Banks 2009; Knight and Richmond 2015; Parkhouse, Lu, and Massaro 2019). According to the US Census Bureau, for example, between 2013 and 2060, the percentage of ethnic minorities in the total US population is expected to increase from $37.6 \%$ to $57 \%$. The census has also shown that "students who speak a language other than English at home represent the fastest-growing segment of the US student population, making up approximately $21 \%$

Saha et al. report that by May 2007 over 1,000 papers had been published in medical and nursing journals mentioning the phrases "cultural competence" or "cultural competency" in their titles or abstracts, of which more than three-quarters have appeared since $2000(2008,1277)$. 
of the school-age population" (cit. in Banks and Banks 2016, xvii). Slovenia seems to be experiencing similar trends. Between the 2015/2016 and 2017/2018 academic years, for example, the number of pupils in Slovenian primary schools who had other than Slovenian citizenship, and concomitantly most likely a different mother tongue, grew from 8,070 to 10,276, an increase of almost 22\% (Republic of Slovenia Statistical Office n.d.). If educators seek to be effective with diverse groups of students, they need a good understanding of their own culture as well as those of their students, i.e. they need adequate cultural competence.

As a concept, culture is difficult to pin down because it is "so all-encompassing, like water to a fish" (Moule and Diller 2019, 90). According to Moule and Diller, culture "is composed of traditional ideas and related values; it is learned, shared, and transmitted from one generation to the next; and it organizes and helps interpret life" $(2019,90)$. The same understanding is to a large extent a part of Gary Weaver's (1986) metaphor of culture as an iceberg whose surface structure above societal sea level comprises items such as food, dress, music, literature, language and other tangible manifestations of culture, while its deep structure, comprising items such as rules of conduct, attitudes or relationships, lies below the surface. Weaver's model has since been adopted and modified by other scholars (e.g., Grant and Sleeter 2007; Dahmardeh and Parsazadeh 2015; Moule and Diller 2019). From the point of view of the present study, Wagner's model allows us to specify the part of culture that was the focus of the empirical part of our study: the surface structure of culture. Although we are aware that the surface and the deep structure represent two sides of the same coin, and that individuals' knowledge of the visible parts of a given culture is interdependent with the underlying deep structure, such as individuals' social interaction or attitudes, the study will nevertheless address the surface structure above all because it can be taken as an objective indicator, which is also easier to verify than the more abstract deep structure.

In the Slovenian context, students' cultural competence has been the subject of several studies. Particularly common has been sociological research on various aspects of cultural competence and academic performance (Klanjšek, Flere, and Lavrič 2007; Flere 2010; Flere et al. 2010). In the narrower sense of the present study, Gadpaille examined classroom activities for translation students involving cultural items from the major English-speaking cultures (2005) and the ways of sensitizing Slovenian high-school graduates to their culture using British and American cartoons (Gadpaille 2008). Hempkin studied the role of critical digital literacy in (inter)cultural and human rights education (2019) and cultural stereotyping among future teachers during a period of increased migration in 2015 (2016). A study similar to the present one was carried out by Zupan in 2007. Also based on a culture quiz, originally developed by Michelle Gadpaille in the undergraduate Intercultural Studies class at the Faculty of Arts in Maribor, the research compared the cultural awareness of undergraduate students of translation and interpreting at the University of Maribor, thematically partly overlapping with the present one. In 2007, the thematic fields, ordered in terms of the students' score, were as follows: Popular Culture; Sports; Organizations, Companies and Media; Politics; and Geography. In addition to the changed thematic foci, the 2019 study differs from that of 2007 in the following respects: in 2019, the sample only includes 1 st year students, while the 2007 sample included undergraduate students from different levels of study; the sample per generation now also includes students from the Department of English and American 
Studies; and, most importantly, our research takes place after more than a decade of rapid technological development, which, as highlighted above, has dramatically changed the ways in which young people access and share information.

\section{Methodology}

Students' cultural awareness was measured with a quiz comprising twenty items, which the students had to identify by offering a concise explanation. Thematically, the questions were divided into five clusters: Culture; Politics; Sports; Current Vocabulary; and Technology. In contrast to the previous study from 2007, the new categories are Technology and Current Vocabulary (new word coinages). These two categories were added because of the ubiquitous impact of technology on all spheres of life in recent years, including the development of new vocabulary among the young. In addition, the category "Pop Culture" was expanded to include items from "serious" culture such as ballet, theater or canonical literature. Quiz items for each category were selected at the authors' discretion and shortlisted based on their relevance and currency, meaning that they had appeared in select American, British and Slovenian online newspapers (e.g. The Guardian, The New York Times, The Daily Mail, Večr, or Delo) between June and September 2019, i.e. in the three-month period leading up to the quiz. Given that the objective was students' overall cultural awareness, the items were not thematically restricted to the English-speaking world; instead, the list included phrases of local, regional and global prominence. The only exception was the category of current vocabulary, which for linguistic reasons was limited to English. As the items indicate, additional criteria (such as distribution over cultural domains) were used to make the selection more representative. Nevertheless, such a restricted selection must necessarily be random at the level of discrimination between one domain item and another, equally current and relevant.

\subsection{Questions}

The Sports section of the study included the names of the Slovenian cyclist Primož Roglič, the winner of the prestigious Grand Tour race Vuelta a España in September, and the Slovenian female sports climber Janja Garnbret, who had also featured significantly in Slovenian media over the summer as the winner of several World Cup competitions; "Tokyo 2020" referred to the next Summer Olympics in Japan, while "Doha 2019" was the location of the World Athletics Championships, taking place at the time of the experiment. The Politics section included Elizabeth Warren, US presidential candidate, and Volodymyr Zelensky, the recently elected President of Ukraine; in addition to the two politicians, "Yellow Vests (gilets jaunes)" was included in the list, referring to the protesters in France, who had been protesting for several months; and "The Backstop", a controversial part of the Brexit agreement between the UK and the EU that had been widely discussed in the media in the weeks before the study. The Culture section included "Edward Clug", renowned international ballet dancer from Maribor; The Testaments, a 2019 novel by Canadian writer Margaret Atwood, which had just been published to much fanfare; "Banksy", an anonymous British street artist and political activist; and "Toni Morrison", a US novelist, who passed away in August 2019. Technology items included "Siri", a virtual assistant in Apple electronic devices; "5G", a cellular network 
technology discussed by the media throughout 2019; "Fortnite", a popular online video game; and "Elon Musk", a technology entrepreneur. Finally, the Vocabulary section included "blackface", the controversial makeup that hit the headlines during the presidential elections in Canada; "bae", a slang term of endearment popular among youth; "woke", referring to a perceived awareness of the problem of social and racial justice; and "whistleblower", denoting a person exposing secret information or action considered illegal.

\subsection{Cohort}

The cohort included 64 first-year students of Guided Writing (Vodeno pisanje), a mandatory course for the students of English and English Translation at the University of Maribor. Fifty $(78.13 \%)$ students were female and $14(21.87 \%)$ male. The mean age was 19.64 years; standard deviation 1.67. The students came from 37 different high schools (two students left this field blank). The highest number of students from the same school was eight and six, from I. gimnazija Maribor and III. gimnazija Maribor, respectively. Apart from four former students of Gimnazija Lava Celje, all other schools were represented by three or fewer students. Fifty-two respondents attended high school in Slovenia; seven in Croatia, two in Serbia; and one in Russia. Fifty-eight students attended general grammar school (gimnazija) programs leading to the General Matura exam, while six attended various vocational programs such as Commerce; Hospitality and Tourism; or Cosmetics, which lead to the Vocational Matura school-leaving exam. Fifty students listed Slovenian as their mother tongue; nine Croatian; two Serbian; one Macedonian; one Portuguese; and one Russian. The mean school-leaving exam grade in English was 4.92. ${ }^{2}$ On average, the respondents reported spending just over two hours a day on the internet.

The quiz took place on 3 October 2019, with all the students deciding to take part in it. After filling out the consent form, including some demographic information, they were administered the quiz on paper. Given that most students were seated next to each other with no seat in between, three versions of the quiz were prepared, each with a different order of the same questions in order to discourage the students from copying answers from their neighbours. The respondents had 20 minutes to complete the quiz. After the quiz, the authors jointly marked the answers and entered the results in a spreadsheet. The scoring scale was as follows: 0 points for an incorrect answer; one point for a partially correct answer; and two points for a correct answer. One point was awarded for answers that showed limited knowledge of a concept (e.g., "sportsman" for "Primož Roglič" or "an app" for "Siri"). The total number of points thus was 40 . The results were statistically processed and analysed.

\section{Results}

The average overall score in the quiz was 12.08 points $(30.2 \%)$. The highest total score was 23 points (57.5\%), achieved by three respondents, who represented $4 \%$ of the cohort; the

Given that the Matura grading system in Slovenia differs from that of the other countries, the average grade was calculated for the graduates of Slovenian high schools only. In Slovenia, the grading scale ranges from one (lowest grade) to five (highest grade). The grade, at the same time, equals the number of points awarded per subject on the Matura exam. In some subjects (including foreign languages), students can earn an additional three points for taking the exam at a higher level of difficulty. 
lowest score was one point, achieved by one student, who represented $1.5 \%$ of respondents. The median was 11 points. The respondents with General Matura on average scored 12.47 points; the respondents with Vocational Matura, on the other hand, scored 9.67 points overall, meaning that their score was $20.59 \%$ lower $^{3}$. Table 1 shows the ranking of items with a total relative number of correct answers; indicated in brackets is the category of item ( $\mathrm{T}$ Technology; V - Vocabulary; S - Sports; C - Culture; P - Politics):

TABLE 1. Result by item.

\begin{tabular}{|c|l|c|c|l|c|}
\hline Rank & Item & $\begin{array}{c}\text { Correct } \\
\text { answers (\%) }\end{array}$ & Rank & Item & $\begin{array}{c}\text { Correct } \\
\text { answers (\%) }\end{array}$ \\
\hline 1 & Siri (T) & 87.50 & 11 & whistleblower (V) & 25.00 \\
\hline 2 & Fortnite (T) & 85.94 & 12 & $\begin{array}{l}\text { Yellow Vests (gilets } \\
\text { jaunes) (P) }\end{array}$ & 21.88 \\
\hline 3 & bae (V) & 78.91 & 13 & $\begin{array}{l}\text { Volodymyr Zelen- } \\
\text { sky (P) }\end{array}$ & 10.94 \\
\hline 4 & Elon Musk (T) & 47.66 & 14 & Janja Garnbret (S) & 10.94 \\
\hline 5 & Tokyo 2020 (S) & 41.41 & 15 & Doha (S) & 5.47 \\
\hline 6 & Primož Roglič (S) & 41.41 & 16 & The Backstop (P) & 3.13 \\
\hline 7 & $5 \mathrm{G} \mathrm{(T)}$ & 38.28 & 17 & $\begin{array}{l}\text { Elizabeth Warren } \\
\text { (P) }\end{array}$ & 3.13 \\
\hline 8 & blackface (V) & 32.03 & 18 & The Testaments (C) & 3.13 \\
\hline 9 & Banksy (C) & 30.47 & 19 & Edward Clug (C) & 3.13 \\
\hline 10 & woke (V) & 29.69 & 20 & Toni Morrison (C) & 2.34 \\
\hline
\end{tabular}

Also calculated were the overall average results for each of the five thematic categories. The results are presented in Table 2 .

TABLE 2. Ranking by category.

\begin{tabular}{|l|l|l|}
\hline Rank & Category & Average score (\%) \\
\hline 1 & Technology & 64.84 \\
\hline 2 & Vocabulary & 41.41 \\
\hline 3 & Sports & 24.80 \\
\hline 4 & Politics & 9.77 \\
\hline 5 & Culture & 9.77 \\
\hline
\end{tabular}

Additionally, the absolute numbers of correct; partially correct; incorrect; and unanswered questions for each individual item were calculated. The results are presented in Table 3.

\section{Discussion}

Quantitative analysis of results made possible several qualitative insights into the students' cultural awareness. Average overall results show that the respondents were most familiar with the

3 Three respondents did not provide information on the type of Matura they took and were excluded from this calculation. The General Matura group thus included 58 respondents, while the Vocational Matura group comprised six. 
TABle 3. Distribution by type of answer.

\begin{tabular}{|l|l|l|l|l|l|}
\hline Rank & Item & Correct & $\begin{array}{l}\text { Partially } \\
\text { correct }\end{array}$ & Incorrect & Blank \\
\hline 1 & Siri & 51 & 10 & 2 & 1 \\
\hline 2 & Fortnite & 50 & 10 & 1 & 3 \\
\hline 3 & bae & 45 & 11 & 3 & 5 \\
\hline 4 & Elon Musk & 28 & 5 & 11 & 20 \\
\hline 5 & Tokyo 2020 & 9 & 35 & 1 & 19 \\
\hline 6 & Primož Roglič & 15 & 23 & 3 & 23 \\
\hline 7 & 5G & 10 & 29 & 5 & 20 \\
\hline 8 & blackface & 16 & 9 & 6 & 33 \\
\hline 9 & Banksy & 15 & 9 & 6 & 34 \\
\hline 10 & woke & 7 & 24 & 14 & 19 \\
\hline 11 & whistleblower & 15 & 2 & 12 & 35 \\
\hline 12 & Yellow Vests (gilets jaunes) & 12 & 4 & 6 & 42 \\
\hline 13 & Volodymyr Zelensky & 6 & 2 & 6 & 50 \\
\hline 14 & Janja Garnbret & 6 & 2 & 5 & 51 \\
\hline 15 & Doha & 1 & 5 & 5 & 53 \\
\hline 16 & The Backstop & 2 & 0 & 3 & 59 \\
\hline 17 & Elizabeth Warren & 2 & 0 & 19 & 43 \\
\hline 18 & The Testaments & 1 & 2 & 20 & 41 \\
\hline 19 & Edward Clug & 2 & 0 & 7 & 55 \\
\hline 20 & Toni Morrison & 1 & 1 & 6 & 56 \\
\hline
\end{tabular}

Technology items. In addition to "Siri" and "Fortnite" at the top of the rankings, "Elon Musk" and " $5 \mathrm{G}$ " were also in the top third of all items. The results for items related to mobile phones and online communities are hardly surprising. According to a study by Dellinger from 2019, as many as $72 \%$ of US consumers have interacted with a voice assistant in the last half year, which in 36\% was Apple's Siri (Dellinger 2019). Recent studies among Slovenian university students have also confirmed that smart phones are the preferred communication device among the young (Bratina 2019). Similarly, Fortnite is popular among the same age group, given that the number of registered Fortnite players exceeded 250 million around the globe in March 2019, of whom almost two-thirds of players are aged 18-24 (Gough 2019). Although these studies are based on US respondents, the results can most likely be transposed to Slovenia. In comparison, "Elon Musk" as a person affiliated with technology was correctly identified by less than half of all respondents $(47.66 \%)$. Compared to the previous two items, this one had a relatively large number of incorrect answers (11), suggesting that the respondents considered Musk familiar ("invented things") but were unable to pin him down. For the latter, he was at best "a rich person". The results for " $5 \mathrm{G}$ " underlined the stereotype of a more pronounced interest in technology among the male respondents, given that $85 \%$ of them identified the item correctly, compared to only $55 \%$ of female students. Forty-five percent of partially correct answers (i.e. 29) at the same time indicates that the respondents again had a general idea of the concept ("phone network speed") but could not be more specific. Its brevity also made 
the phrase vulnerable to confusion with the acronym of the international intergovernmental organization "G7", which happened to hold an important summit just weeks before the quiz, as at least one respondent ("political group of countries") indicated.

The word that stood out in the Vocabulary category was "bae", which was recognized by over three-quarters of the respondents $(78.91 \%)$. Its recognizability did not surprise, given that this slang word of endearment represents a typical acronym ("before anything else") used by "teens and young adults" on social media (Moreau 2019). It should be noted that several respondents correctly identified the item as the expression for "poop" in Danish, which is one of the meanings that came to prominence following the discussions about the word "bae" in the title of a song by a famous American singer and rapper, Pharrell Williams (Moreau 2019). Another slang word "woke" was considerably less well known (29.69\%) than "bae". At the same time, however, this item had the highest number of partially correct (24) and incorrect (14) answers, i.e. of attempts, which suggests that the respondents had the concept somewhere at the back of their mind (e.g., "being aware") but were unable to be more specific about it. With one notable exception, none of the eight respondents ignorant of "bae" managed to correctly identify "woke", which probably indicates that they were generally unfamiliar with informal slang vocabulary. A marginally higher number of respondents $(32.03 \%)$, on the other hand, recognized "blackface", although it was not a word typically associated with the younger generation alone. However, it was current at the time of the quiz because of a scandal involving Canadian Prime Minister Justin Trudeau (Carlisle and Kambhampaty 2019). It is indicative that this item had more than twice as many blanks (33 unattempted answers) than partial or incorrect answers combined (nine plus six), which suggests that the respondents did not even try to guess its meaning, presumably because it was completely unknown to them. On the other hand, some respondents had a clear idea and generated accurate descriptions such as "derogatory appropriation of African features". "Whistleblower" differed from the three other items in the category in that the respondents either correctly identified its metaphorical meaning ("one who releases sensitive information to the public") and one of the most prominent whistleblowers in recent years, Julian Assange, or only sought its literal meaning in relation to the whistle as an instrument for producing sound.

Among "Sports" items, the top two were "Tokyo 2020" and "Primož Roglič", each with $41.41 \%$ of correct answers. "Tokyo 2020 " had nine correct answers and 35 were partially correct. What the authors considered a correct answer comprised variants of "Summer Olympics", while "Olympics", for example, was worth half the points. Combined, the two types of answers still accounted for $68.75 \%$ of the answers, which shows that the Olympics is one of the most recognizable sporting events. The item has also confirmed the stereotype that sport is typically followed more often by males, given that more than $85 \%$ of male respondents correctly identified the Olympics, compared to $64 \%$ of female respondents. Similarly, Primož Roglič was correctly identified (15) or partially identified (23) by $59.37 \%$ of all respondents, and partially correct answers included answers such as "cycling" or "sportsman". Not so surprisingly, only one student out of the ten who attended high school outside Slovenia correctly identified the Slovenian cyclist. Interestingly, the male cyclist was only slightly better known among the male students $(64 \%)$ than their female colleagues $(58 \%)$, most likely because of extensive coverage of his achievements in the Slovenian media. 
"Janja Garnbret" and "Doha" had notably lower scores with 10.94 and 5.47\%, respectively. Given that this pair has a similar structure as the previous one (Slovenian athlete and a major international sporting event), the lower scores probably reflect the different popularity levels of different sports. For example, while the International Cycling Union represented 194 national federations and over a million licensed competitors in 2018 (The Union Cycliste Internationale 2018: 10), the International Federation of Sport Climbing only had 2,160 licensed athletes in 65 countries (IFSC 2019). In turn, fan bases are most likely relatively proportionate to the popularity, although the fan base for climbing in Slovenia has been increasing, among young adults, following Garnbret's results. Having only one correct identification of the athletics championship in Doha, on the other hand, is to some extent surprising, given that athletics has been a relatively popular sport in Slovenia. On the other hand, Slovenia has not had a truly successful athletics champion for several years, which may have caused a decline in the popularity of this sport. Another observation to make is that of the eight respondents who correctly identified "Janja Garnbret", seven identified, correctly or partially correctly, at least three out of four sports items, suggesting that this group of respondents was paying attention to the sporting news.

Given that "Generation $\mathrm{Z}$ have already determined that they don't like [politics] and are disgusted, disenchanted, and discouraged by the whole political system in general" (Seemiller and Grace 2019,262), it comes as no surprise that the Politics items had a low overall score $(9.77 \%)$ in the quiz. Among the four items on the list, "Yellow Vests (gilets jaunes)" stood out at the top with $21.88 \%$, which to some extent confirms the observation that, although it detests politics, Generation $\mathrm{Z}$ is concerned about societal matters (Seemiller and Grace 2019, 249), which form part of the agenda of the French protesters. What is interesting in this category is the gender gap among the responders. While 39.29\% of male students correctly identified the item, only $17 \%$ of female students did so. Although we can speculate about reasons, one possible explanation is that the protests have attracted more attention from male students because of the associated violence. On the other hand, this result seems to be an anomaly compared to the results for the other three political items. The Ukrainian president yielded equally low results $(10.94 \%)$, regardless of the respondent's gender: among male students, $14.29 \%$ identified this item correctly or partially correctly ("politician"), compared to $12 \%$ of female students. However, the most surprising result in the category concerned "The Backstop" and "Elizabeth Warren". Given that the respondents comprised English students and students of English Translation, it was assumed that they would be familiar with at least one of these terms. However, that was not the case, as only two students (3.13\%) recognized each item correctly. Moreover, none of these four students was able to recognize both items from the English-speaking world. In fact, with the exception of one student, no respondent was able to correctly or at least partially correctly identify at least three political items out of four. Given that both "The Backstop" and "Elizabeth Warren" featured prominently in practically all news media in the English-speaking world, this to some extent conflicts with the claim of almost $80 \%$ of the respondents that they had been following the news in the British and/or American newspapers over the three months prior to the quiz. What further corroborates unfamiliarity with the political items was the high number of items left blank for all four items, ranging from 42 blanks (unattempted answers) to as many as 59 with "the Backstop". What also makes "Elizabeth Warren" different from the rest of the 
items was that she garnered the second-highest number (19) of incorrect answers. She was described as a "British politician" or "ghost hunter". While both answers are incorrect, the second is interesting because the respondent evidently mistook the US politician for Edward Warren Miney, an American paranormal investigator, associated with prominent cases of hauntings, which suggests a niche interest in our students' cultural awareness.

Finally, the category that had the same average score as "Politics" (3.77\%) was "Culture". In contrast to "Politics", however, where the results of all four items were ranked close to one another, "Banksy" stood out in ninth place overall, with $30.47 \%$, ten times the score of the other three items. In addition to fifteen correct answers, "Banksy" also had nine partially correct answers (combined 37.5\%), indicating that just over a third of the students were familiar with the British street artist. In comparison, the three other items representing "high culture" did considerably worse with similarly low percentage numbers of correct identification. Margaret Atwood's novel The Testaments and the recently deceased American writer Toni Morrison were correctly identified only by one respondent each (not the same one). In addition, each of these two also had one partially correct answer. What separates "The Testaments" from "Toni Morrison" was that the former had the highest number (20) of incorrect answers for somewhat obvious reasons: the students disregarded or missed the italics and had it mixed up with the "new \& old Testaments" from the Bible. Contemporary North American literature did not do well either; however, by comparison, the well-known Slovenian ballet dancer Edward Clug from Maribor had even lower results, with as many as 56 blanks, suggesting that the respondents were not familiar with ballet. Not surprisingly, both students who recognized him graduated from a Maribor high school. Another observation that must be highlighted is that one student managed to correctly identify four items from the Culture section, but not "The Testaments". Not surprisingly, her overall performance was rather high, with 21 points placing her score in fourth place.

In addition to the results across individual categories, the analysis also provided information about the respondents. At the top of the ranking were three students who each scored 23 points; two of them were Slovenian, the third was a Croat, who had completed high school in his home country. The two top scoring students had above-average grades in English at the General Matura (five ${ }^{4}$ and eight); the third one had a four, which was below the 4.92 average. All three achieved similar results across the clusters, doing very well in the Technology and Vocabulary sections and achieving similar results in Sports, Politics and Culture, with some variation across each individual cluster. The next group also comprised three students, who each scored 21 points. All had graduated from high schools in Slovenia. The distribution of their correct answers was similar to that of the top three respondents. One of these three students had a relatively low score in Politics, where she correctly identified only one item; however, she excelled in the Culture section, correctly identifying all items except for "The Testaments". The same student also had a relatively good grade in English at the Matura (six).

One interesting observation is that male students achieved better results than their female counterparts. On average, males scored 15.14 points (37.85\%) on the quiz, while female

The student was from Croatia, where 5 is the highest possible grade. 
students scored 11.22 points (28.05\%). The scores of male students were better across all five categories. In the "Technology" section, for example, the score of the males was $75.98 \%$, compared to $61.75 \%$ for females. Similarly, the margin was noticeable in Culture, where males' score was $14.29 \%$, and the females' $8.50 \%$. The results correlate well with the average grades in English at the Matura: while the male respondents averaged a grade of 4.79, female respondents' grade averaged 3.86, the margin suggesting that a higher grade also means better cross-cultural awareness.

\section{Conclusion}

These culture quiz results partly overlap with the results of a previous similar study (Zupan 2007), at the same time providing new insights. While "Popular Culture" had the highest overall score twelve years ago, it has now been replaced by "Technology", which suggests a noticeable shift. However, given that "Technology" comprised items that are closely related to telecommunications and the virtual world, both an integral part of the digital reality of today's younger generations, then the shift is less surprising. The same trend is corroborated by the results in the "Vocabulary" section, where "bae", an expression used by the young that is directly connected with communication, also exhibited a high level of prominence. On the other hand, the quiz reaffirmed Sport as a relatively stable category, given that it was ranked second in 2007 and third in 2019. Similarly, the results of the quiz confirmed that politics is a field of relatively little interest to the young, with a low total score even after more than a decade of instant access to global news and events. The 2019 quiz also confirmed "culture" to be a broad category. The prominence of popular culture items over the decade, on the one hand, and very low scores on "high" culture items, on the other hand, may suggest a possibly worrying trend because when things such as literature, works of art, scholarship or philosophy that represent a shared frame of reference among educated people disappear, "high culture is superseded by a culture of fakes" (Scruton 2012).

In the light of these findings, the authors anticipate further testing on participant samples expanded to allow comparative testing on different age cohorts, study subjects and faculties, using an online platform. Moreover, the criteria for item selection should be enlarged and could even be redesigned in future to include student input, as a means of retaining generational relevance.

\section{References}

Baker, Will. 2012. "From Cultural Awareness to Intercultural Awareness: Culture in ELT." ELT Journal 66 (1): 62-70. https://doi.org/10.1093/elt/ccr017.

Banks, James A., ed. 2009. The Routledge International Companion to Multicultural Education. New York: Routledge.

Banks, James A., and Cherry A. McGee Banks. 2016. Multicultural Education: Issues and Perspectives. Hoboken, NJ: Wiley.

Berger, Peter L., and Thomas Luckmann. 1966 (1991). The Social Construction of Reality: A Treatise in the Sociology of Knowledge. London: Penguin Books.

Bratina, Tomaž. 2019. "Mobile Phones and Social Behavior among Millennials - Future Teachers." Revija za elementarno izobraževanje 12 (4): 315-30. https://doi.org/10.18690/rei.12.4.315-330.2019. 
Carlisle, Madeleine, and Anna Purna Kambhampaty. 2019. "Justin Trudeau Says He Didn't Remember Blackface and Brownface Photos and Admits There Could Be More.” Time, September 19, 2019. https://time.com/5681605/justin-trudeau-blackface-more-photos/.

Castles, Stephen. 2009. "World Population Movements, Diversity, and Education.” In The Routledge International Companion to Multicultural Education, edited by James A. Banks, 49-61. New York: Routledge.

Collins COBUILD Advanced English Dictionary, s.v. "cultural awareness," accessed May 24, 2020. https:// www.collinsdictionary.com/dictionary/english/cultural-awareness.

Dahmardeh, Mahdi, and Hossein Parsazadeh. 2015. "Language and Culture: Can We Shape What the Future Holds?" Cultura. International Journal of Culture and Axiology 12 (2): 61-72. https://doi.org /10.5840/cultura201512221.

Daugherty, Heather N., and Rachel C. Kearney. 2017. "Measuring the Impact of Cultural Competence Training for Dental Hygiene Students." The Journal of Dental Hygiene 91 (5): 48-54. https://jdh.adha .org/content/91/5/48.

Dellinger, AJ. 2019. "Survey Says Siri and Google Assistant Are the Most Used Voice Assistants." Digital Trends, April 30, 2019. https://www.digitaltrends.com/home/siri-google-asistant-most-used-voice -assistants-alexa/.

EMT Expert Group. 2009. "Competences for Professional Translators and Experts in Multilingual and Multimedia Communication.” Accessed May 23, 2020. https://ec.europa.eu/info/sites/info/files/emt _competences_translators_en.pdf.

Eyckmans, June. 2017. "Cultural Competence in Translation Studies and Its Assessment." In Towards Transcultural Awareness in Translation Pedagogy, edited by Julie Deconinck, Philippe Humblé, Arvi Sepp, and Hélène Stengers, 209-29. Berlin/Zürich: LIT Verlag. http://hdl.handle.net/1854/LU -8552979 .

Flere, Sergej. 2010. Kdo je uspešen v slovenskih šlah? Ljubljana: Pedagoski inštitut.

Flere, Sergej, Marina Tavčar Krajnc, Rudi Klanjšek, Bojan Musil, and Andrej Kirbiš. 2010. "Cultural Capital and Intellectual Ability as Predictors of Scholastic Achievement: A Study of Slovenian Secondary School Students." British Journal of Sociology of Education 31 (1): 47-58. https://doi.org/10 $.1080 / 01425690903385428$.

Gadpaille, Michelle. 2005. "Cutting Edge Culture for Novice Translators." ELOPE 2 (1/2): 245-53. https://doi.org/10.4312/elope.2.1-2.245-253.

—. 2008. "Culture for the Culturally Desensitized." In Culture-Bound Translation and Language in the Global Era, edited by Aleksandra Nikčević-Batrićević, and Marija Knežević, 77-83. Newcastle (UK): Cambridge Scholars.

González Davies, Maria, and Christopher Scott-Tennent. 2005. "A Problem-Solving and Student-Centred Approach to the Translation of Cultural References." Meta 50 (1): 160-79. https://doi.org/10.7202 /010666ar.

Gough, Christina. 2019. “Number of Registered Players of Fortnite Worldwide 2019.” Statista, October 18, 2019. Accessed November 20, 2019. https://www.statista.com/statistics/746230/fortnite-players/.

Grant, Carl A., and Christine E. Sleeter. 2007. Doing Multicultural Education for Achievement and Equity. New York: Routledge.

Hale, Sandra. 2014. "Interpreting Culture. Dealing with Cross-Cultural Issues in Court Interpreting." Perspectives: Studies in Translatology 22 (3): 321-31. https://doi.org/10.1080/0907676X.2013.827226.

Hempkin, Kirsten. 2016. "Exploring Student Attitudes to the Refugee Crisis: Songs on Migration." ELOPE 13 (1): 111-21. https://doi.org/10.4312/elope.13.1.111-121.

—. 2019. "Fake News and Alternative Facts: Critical Digital Literacy in the Classroom." IATEFL Slovenia Magazine 75: 4-6. http://www.iatefl.si/files/2019/03/Winter-2019-IN-75.pdf.

Holland, Karen. 2018. Cultural Awareness in Nursing and Health Care: An Introductory Text. London: Routledge.

IFSC. 2019. “Key Figures”. Accessed November 22, 2019. https://www.ifsc-climbing.org/index.php/about -us/key-figures. 
ISO. 2015. "Translation Services - Requirements for translation services (SIST EN ISO 17100).” Accessed May 24, 2020. https://www.iso.org/standard/59149.html.

Kerber Kate, Fariba Kolahdooz, Meeka Otway, Melinda Laboucan, Se Lim Jang, Sue Lawrence, Suzanne Aronyk, Matthew Quinn, Stephanie Irlbacher-Fox, Crystal Milligan, Sabrina Broadhead, Debbie DeLancey, Andre Corriveau, and Sangita Sharma. 2019. "Opportunities for Improving Patient Experiences among Medical Travellers from Canada’s Far North: A Mixed Methods Study." BMJ Open 9: e030885. https://doi.org/10.1136/bmjopen-2019-03088.

Klanjšek, Rudi, Sergej Flere, and Miran Lavrič. 2007. "Kognitivni in družbenoekonomski dejavniki šolskega uspeha v Sloveniji.” Družboslovne razprave 23 (55): 49-69. https://www.druzboslovne -razprave.org/pdf/clanki/55-klanjsek_flere_lavric.pdf.

Knight, Caroline, and Jamia Thomas Richmond. 2015. "Breaking the Mold: Challenging Prevailing Myths through Cross-Cultural Experiences." In The Ethics of Cultural Competence in Higher Education, edited by Beverly A. Burnell and Heidi L. Schnackenberg, 99-110. Oakville: Apple Academic Press.

McAllister, Gretchen, and Jacqueline Jordan Irvine. 2000. "Cross Cultural Competency and Multicultural Teacher Education.” Review of Educational Research 70 (1): 3-24. https://doi.org/10.3102 $\% 2 \mathrm{~F} 00346543070001003$.

Moule, Jean, and Jerry V. Diller. 2012. Cultural Competence: A Primer for Educators. Belmont, CA: Wadsworth.

Moreau, Elise. 2019. “What Does 'Bae’ Mean?” Lifewire, November 11, 2019. Accessed November 21, 2019. https://www.lifewire.com/what-does-bae-mean-3485960.

Parekh, Ranna. 2014. The Massachusetts General Hospital Textbook on Diversity and Cultural Sensitivity in Mental Health. New York, NY: Springer New York.

Parkhouse, Hillary, Chu Yi Lu and Virginia R. Massaro. 2019. "Multicultural Education Professional Development: A Review of the Literature.” Review of Educational Research 89 (3): 1-43. https://doi.or g/10.3102\%2F0034654319840359.

Paez Kathryn A., Jerilyn K. Allen, Mary Catherine Beach, Kathryn A. Carson, and Lisa A. Cooper. 2009. "Physician Cultural Competence and Patient Ratings of the Patient-Physician Relationship." Journal of General Internal Medicine 24 (4): 495-98. https://doi.org/10.1007/s11606-009-0919-7.

Saha, Somnath, Mary Catherine Beach, and Lisa A. Cooper. 2008. "Patient Centeredness, Cultural Competence and Healthcare Quality." Journal of the National Medical Association 100 (11): 1275-85. https://doi.org/10.1016/S0027-9684(15)31505-4.

Scruton, Roger. 2012. "High Culture is Being Corrupted by a Culture of Fakes." The Guardian, December 19, 2019. https://www.theguardian.com/commentisfree/2012/dec/19/high-culture-fake.

Seemiller, Corey, and Meghan Grace. 2019. Generation Z: A Century in the Making. London: Routledge.

Shaules, Joseph. 2019. Language, Culture and The Embodied Mind: A Developmental Model of Linguaculture Learning. Singapore: Springer Verlag.

Shepherd, Stephane M., Cynthia Willis-Esqueda, Danielle Newton, Diane Sivasubramaniam, and Yin Paradies. 2019. "The Challenge of Cultural Competence in the Workplace: Perspectives of Healthcare Providers." BMC Health Services Research 19 (135): 4-11. https://doi.org/10.1186/s12913-019-3959-7.

Suárez-Orozco, Marcelo M., and Desireé Baolian Qin-Hilliard. 2004. "Globalization: Culture and Education in the New Millenium." In Globalization: Culture and Education in The New Millennium, edited by Marcelo M. Suárez-Orozco and Desirée Qin-Hilliard, 1-37. Berkeley, California: University of California Press.

Republic of Slovenia Statistical Office (SURS). n.d. "Pupils with Foreign Citizenship by Country of Citizenship and School Year." Accessed November 1, 2019. https://pxweb.stat.si/SiStat/en.

Tellinger, Dušan. 2016. "On Interpreter's Intercultural Awareness.” Opera Slavica XXVI (2): 49-55. https://digilib.phil.muni.cz/xmlui/bitstream/handle/11222.digilib/135560/2_OperaSlavica_26-2016 -2_7.pdf?sequence=1.

Turudić, Momir. 2008. "A sada bilo Ti sretno i do viđenja." Vreme, February 14, 2008. Accessed May 24, 2020. https://www.vreme.com/cms/view.php?id=584894. 
The Union Cycliste Internationale (UCI). 2018. “UCI annual report 2018.” Aigle: UCI. Accessed May 24, 2020. https://www.uci.org/docs/default-source/publications/2018-uci-rapport-annuel-inside-english -web.pdf.

Weaver, Gary R. 1986. "Understanding and Coping with Cross-Cultural Adjustment Stress." In CrossCultural Orientation: New Conceptualizations and Applications, edited by R.M. Paige, 134-46. Lanham MD: University Press of America.

Zupan, Simon. 2007. "Lance Armstrong - First Man on the Moon?: Cultural Awareness in Students of Translation and Interpreting." In English Language, Literature and Culture in a Global Context, edited by Nada Šabec, 43-44. Maribor: Filozofska fakulteta. 